\title{
Modification of the Serum Bromide Assay for the Measurement of Extracellular Fluid Volume in Small Subjects
}

\author{
Robert A. Drongowski, M.S., ${ }^{1}$ ARnOld G. Coran, M.D., ${ }^{2}$ \\ AND JOHN R. WESLEY, M.D. ${ }^{3}$ \\ Section of Pediatric Surgery, Mott Children's Hospital, University of Michigan Medical School, \\ Ann Arbor, Michigan 48109
}

Submitted for publication March 5, 1982

\begin{abstract}
Serum bromide has heen used in the past to measure extracellular fluid volume in infants. In this report, a modification and refinement of a previously described spectrophotometric assay suitable for determining bromide levels in blood is presented. The assay involves sample deproteinization with perchloric acid followed by spectrophotometric analysis of the complexes formed by the reaction between sodium bromide and gold chloride. Linear standard curves were obtained by diluting 1:2 with pooled serum at the following bromide concentrations: $10,20,30$ and $40 \mathrm{mg} \%$. Intra- and interassay variation using this technique was extremely small $(n=6$, correlation coefficient, 0.995 , and $n=5$, correlation coefficient, 0.988 , respectively). For toxicological analysis, a linear standard curve was derived from sodium bromide standards at the following concentrations: $40,60,80$, and $100 \mathrm{mg} \%$. The reproducibility and reliability of this assay have been excellent and the correlaton with neutron activation analysis was excellent. The assay is easily adapted for the analysis of large numbers of samples, is easy to perform, and requires only small sample volumes.
\end{abstract}

\section{INTRODUCTION}

Measurement of extracellular fluid volume in infants is very helpful in the evaluation of various treatment programs such as total parental nutrition and the fluid resuscitation of shock states. In the adult, these studies are frequently performed using radioactive isotopes. In infants, however, the use of radioactive isotopes is precluded. The nonradioactive isotope sodium bromide has been used in the past to measure extracellular fluid in infants [1-3]. However, several different techniques have been reported for determining the bromide ion concentration in biological fluids. Direct spectroscopy [4], neutron activiation analysis [5], diffusion techniques [6], and ion selective electrodes [7] have been used. These various methods

\footnotetext{
${ }^{1}$ Research Associate, Pediatric Surgery Research Laboratories, Mott Children's Hospital, Ann Arbor, Michigan. To whom reprint requests should be addressed.

${ }^{2}$ Head of the Section of Pediatric Surgery, Professor of Surgery, University of Michigan Medical School.

${ }^{3}$ Assistant Professor of Surgery, Section of Pediatric Surgery, University of Michigan Medical School.
}

have their own disadvantages. There are interferences in direct spectroscopy and ion selective methodology, diffusion techniques are not very accurate, and neutron activation analysis is cumbersome and expensive.

Of the techniques available, direct spectroscopy is the most appealing. Multiple samples may be analyzed quickly and precisely with very small sample volumes. We have significantly modified a spectrophotometric assay for bromide, initially reported by Wolf and Eadie [8] and subsequently modified by Cassady [4], in order to increase its reproducibility and reliability. The assay reported is easy to perform, uses small sample volumes, and correlates well with neutron activation analysis.

\section{MATERIALS AND METHODS}

Mongrel puppies, weighing between 3.0 and $5.0 \mathrm{~kg}$, and fasted overnight were anesthetized with $25 \mathrm{mg} / \mathrm{kg}$ of pentobarbitol intravenously. Catheters were inserted into the femoral artery and vein. A $5 \%$ sodium bro- 


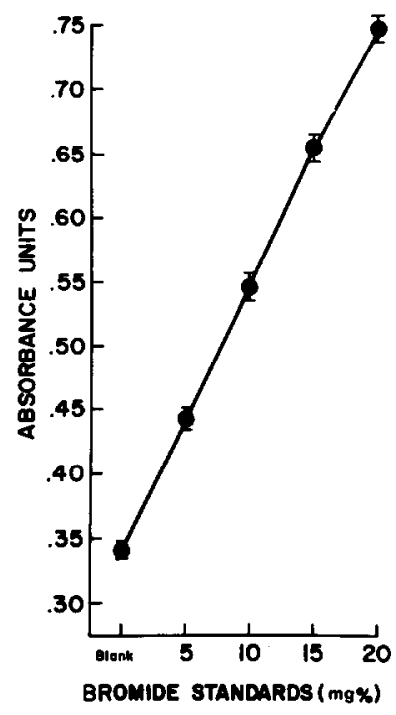

FIG. 1. Bromide assay standard curve.

mide $(\mathrm{NaBr})$ solution in a dose of $4 \mathrm{ml} / \mathrm{kg}$ body weight was injected into the femoral vein and blood samples were collected from the femoral artery at the following time intervals: prior to injection of the $\mathrm{NaBr}$ and every $30 \mathrm{~min}$ after injection for a total of 3 hr. The blood samples were centrifuged at $2000 \mathrm{rpm}$ for $15 \mathrm{~min}$ at $4^{\circ} \mathrm{C}$ and the serum removed.

The assay is performed in the following way: $0.5 \mathrm{cc}$ of a standard or unknown sample is deproteinized in $1.0 \mathrm{cc}$ of ice cold perchloric acid $(0.6 \mathrm{M})$. Following centrifugation at $2000 \mathrm{rpm}$ at $4^{\circ} \mathrm{C}$ for $5 \mathrm{~min}, 1 \mathrm{cc}$ of supernatant is transferred to a test tube containing $1.0 \mathrm{cc}$ of $0.6 \%$ sodium chloride $(\mathrm{NaCl})$ and $1.0 \mathrm{cc}$ of $0.0375 \%$ gold chloride $\left(\mathrm{AuCl}_{3}\right)$. Absorbance is recorded with a spectrophotometer at $350 \mathrm{~nm}$ wavelength exactly $3 \mathrm{~min}$ after the addition of the supernatant to the $\mathrm{NaCl}-\mathrm{AuCl}_{3}$ solution. The spectrophotometer is zeroed with distilled water. The standards used in the assay are $5,10,15$, and $20 \mathrm{mg} \% \mathrm{NaBr}$ made up with double-distilled deionized water. The assay is linear up to a concentration of $\mathrm{NaBr}$ of $40 \mathrm{mg} \%$. All curves were derived from linear regression analysis.

\section{RESULTS}

A typical standard curve is shown in Fig. 1. The correlation coefficient for this data is $0.997(n=7)$. The results of the analysis of the pooled serum were quite reproducible with means \pm standard deviations of 0.166 \pm 0.33 and $13.17 \pm 0.52 \mathrm{mg} \%(n=10)$ for a typical low and high pooled serum concentration. No significant differences were observed between plasma and serum samples.

Sodium chloride was included in the assay system in order to control for a slight degree of cross-reactivity between chloride and bromide. One, 5 , and $10 \% \mathrm{NaCl}$ concentrations were assayed for bromide $(n=8)$ to determine if $\mathrm{NaCl}$ cross-reacts significantly in this assay system. The following values were obtained: $0.233 \pm 0.87,0.50 \pm 0.84$, and 0.46 $\pm 0.59 \mathrm{mg} \%$ (mean $\pm \mathrm{SD}$ ). From these data, it was concluded that $\mathrm{NaCl}$ does not significantly interfere with the bromide determination and that inclusion of $1.0 \mathrm{cc}$ of $0.6 \%$ $\mathrm{NaCl}$ in the assay system protects against chloride variation between samples.

It was observed that serum samples respond differently than standards in the assay. Serum samples reach a peak absorbance 3 min after the addition of the supernatant to the $\mathrm{AuCl}_{3}-\mathrm{NaCl}$ solution. Following this peak, the samples continue to lose absorbance over time (Fig. 2). The standards

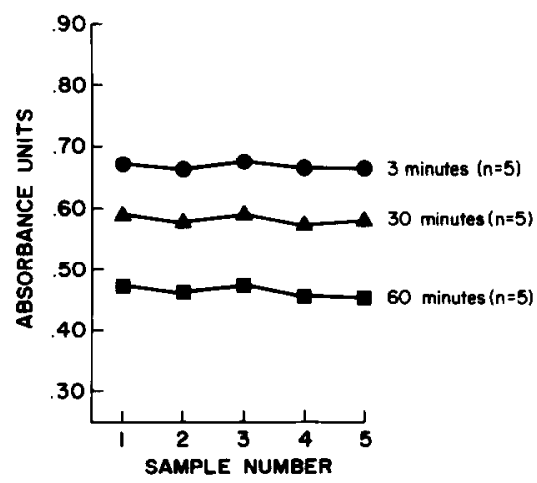

FIG. 2. Change in bromide sample absorbance with time. 
which are made up with distilled water are stable and do not change absorbance over time. Therefore, standards of $10,20,30$, and $40 \mathrm{mg} \%$ diluted 1:2 with pooled serum werc prepared. These standard samples responded in the same manner as the unknown serum samples. Figure 3 shows the intraassay variation using this technique ( $n=6$, correlation coefficient, 0.995 ). Interassay variation using these standard samples is depicted in Fig. 4 ( $n=5$, correlation coefficient, 0.988). An example of a typical group of samples taken from an experimental animal and assayed using the described method and nuclear activation analysis is presented in Fig. 5.

\section{DISCUSSION}

This modification of the spectrophotometric assay for serum bromide differs from the method described by Cassady in several important aspects. First, deproteinization of the serum sample with perchloric acid rather than zinc hydroxide is important since incomplete protein precipitation often results in spurious data and poor reproducibility. By keeping the entire procedure in an acid environment, the reliability of the assay system is greatly improved. Second, it is important to read the peak absorbance value at $3 \mathrm{~min}$,

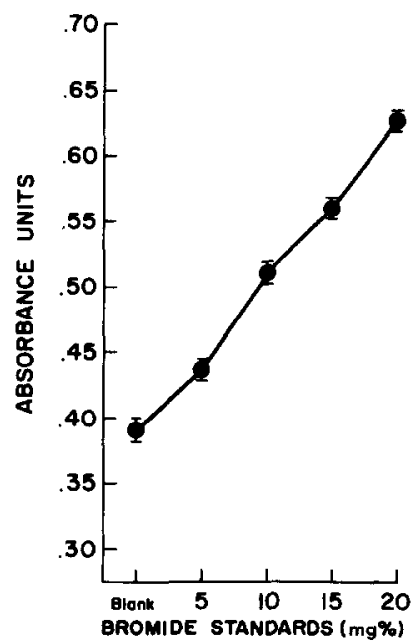

FIG. 3. Intraassay variation for bromide standard curve (diluted 1:2 with pooled serum) $(n=6)$.

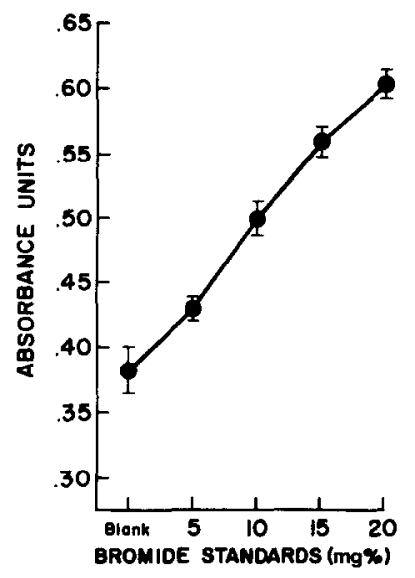

FIG. 4. Interassay variation for bromide standard curve (diluted 1:2 with pooled serum) $(n=5)$.

rather than at $15 \mathrm{~min}$, because significant decreases in absorbance occur over time. Lastly, it is necessary to use standards diluted 1:2 with pooled serum in order to achieve the correct bromide value. Otherwise, the bromide concentration is falsely low. This was substantiated by comparison with neutron activation analysis.

The attractiveness of this assay prompted us to evaluate its use at higher serum concentrations of bromide such as occur with medication overdose. For toxicological analysis, a linear relationship exists using standards at the following $\mathrm{NaBr}$ concentrations: $40,60,80$, and $100 \mathrm{mg} \%$. The only procedure modification required with this range of bromide standards was the use of $2 \mathrm{cc}$ of

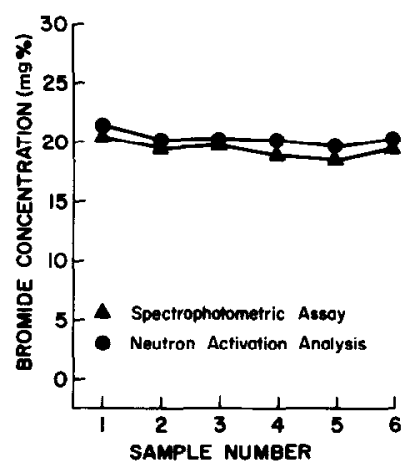

FIG. 5. Comparison of spectrophotometric bromide assay with neutron activation analysis. 
$0.0375 \% \mathrm{AuCl}_{3}$ instead of $1 \mathrm{cc}$ as was described previously. With these modifications, a linear curve is obtained with bromide concentrations between 40 and $100 \mathrm{mg} \%$, an appropriate range for toxicological assays.

The reproducibility and reliability of this assay has been excellent and the correlation with neutron acitivation analysis has been very close. The assay is easily adapted for large numbers of samples by carefully staggering the addition of the supernatant to the $\mathrm{AuCl}_{3}-\mathrm{NaCl}$ solution at $15-\mathrm{sec}$ intervals and by analyzing the samples in blocks of 12 during each 3-min intcrval.

\section{REFERENCES}

1. Finley, S. C., and Hare, R. S., Bromide space in infants and children. AMA Dis. Child 98: 749, 1959.
2. Brans, Y. W., Sumners, J. E., Dweck, H. S., Bailey, P. E., and Cassady, G., Feeding the low-birthweight infant: Orally and parenterally?: II Corrected bromide space in parenterally supplemented infants. Pediatrics 58: 809, 1979.

3. Fink, C. W., and Cheek, D. B., The corrected bromide space (extracellular volume) in the newborn. Pediatrics 26: 379, 1960.

4. Cassady, G., Bromide space studies in infants of low birth weight. Pediat. Res. 4: 14, 1970.

5. Bowen, H. J. M., The determination of chlorine, bromide and iodide in biological material by activation analysis. Biochem. J. 73: 381, 1959.

6. Graystone, J. E., and Ortgies, A. M., Microdiffusion analysis. In D. B. Cheek (Ed.), Human Growth. Philadelphia: Lea \& Febiger, 1968. P. 656.

7. Degenhart, H. J., Albeln, G., Bevaart, B., and Baks, J., Estimation of $\mathrm{Br}^{-}$in plasma with a $\mathrm{Br}^{-}$selection electrode. Clin. Chim. Acta 38: 217, 1979.

8. Wolf, R. L., and Eadie, G. S., Reabsorption of bromide by the kidney. Amer. J. Physiol. 163: 436, 1950. 